doi: $10.12957 /$ childphilo.2020.47899

\title{
mapping identity prejudice: \\ locations of epistemic injustice in philosophy for/with children
}

\author{
peter paul ejera elicor ${ }^{1}$ \\ ateneo de davao university \\ university of santo tomas, graduate school, philippines \\ orcid id: https:/ / orcid.org/0000-0002-6427-0582
}

\begin{abstract}
This article aims to map the locations of identity prejudice that occurs in the context of a Community of Inquiry. My claim is that epistemic injustice, which usually originates from seemingly 'minor' cases of identity prejudice, can potentially leak into the actual practice of $\mathrm{P} 4 \mathrm{wC}$. Drawing from Fricker, the various forms of epistemic injustice are made explicit when epistemic practices are framed within concrete social circumstances where power, privilege and authority intersect, which is observable in school settings. In connection, despite the pedagogical improvements $\mathrm{P} 4 \mathrm{wC}$ offers, some forms of identity prejudice prevalent in traditional classrooms may persist, affecting children who are identified with negatively stereotyped social groups. It is, therefore, important to pay attention to the reality of epistemic injustice and the possible locations where it may potentially surface in the COI. Drawing from my $\mathrm{P} 4 \mathrm{wC}$ experience, I show that identity prejudice stems from the intersections of the roles and positionalities of the participants in a philosophical dialogue. These intersections point towards the epistemic relationships of the $\mathrm{P} 4 \mathrm{wC}$ teacher, the students, and the $\mathrm{P} 4 \mathrm{wC}$ program itself. I conclude that identity prejudice arises circumstantially and/or substantively in P4wC scholarship and practice.
\end{abstract}

keywords: epistemic injustice, testimonial and hermeneutic injustice, identity prejudice, community of inquiry, philosophy for/with children

\section{mapeando preconceito de identidade: locais da injustiça epistêmica na filosofia para/com crianças}

\section{resumo}

Este artigo tem como objetivo mapear os locais de preconceito de identidade que podem se manifestar no contexto de uma Comunidade de Investigação. $\mathrm{O}$ argumento aqui é que a injustiça epistêmica, que geralmente começa com casos aparentemente "menores" de preconceito de identidade, poderia potencialmente vazar para a prática real do FcpC. Partindo de Fricker, as várias formas de injustiça epistêmica são explicitadas quando as práticas epistêmicas são enquadradas em circunstâncias sociais concretas em que poder, privilégio e autoridade se cruzam, o que é observável nos ambientes escolares. Em conexão, apesar das melhorias pedagógicas oferecidas pela FcpC, algumas formas de preconceito de identidade prevalecentes nas salas de aula tradicionais podem persistir, afetando crianças identificadas com grupos sociais estereotipados negativamente. Portanto, é importante prestar atenção à realidade da injustiça epistêmica e aos possíveis locais onde ela pode surgir potencialmente na COI. Com base na minha experiência na FcpC, mostro que o preconceito

${ }^{1}$ E-mail: peterelicor@gmail.com 
mapping identity prejudice: locations of epistemic injustice in philosophy for/with children

de identidade decorre das interseções dos papéis e posicionamentos dos participantes de um diálogo filosófico. Essas interseções apontam para as relações epistêmicas do professor de $\mathrm{FcpC}$, dos alunos e do próprio programa de FcpC. Concluo que o preconceito de identidade surge circunstancial e/ou substancialmente na bolsa de estudos e na prática da FcpC.

palavras-chave: injustiça epistêmica; testemunho e injustiça hermenêutica; preconceito; comunidade de investigação; filosofia para/com crianças

\section{mapeo de prejuicios de identidad: ubicaciones de injusticia epistémica en filosofía para/con niños}

\section{resumen}

Este artículo tiene como objetivo mapear prejuicios de identidad que pueden manifestarse en el contexto de una Comunidad de Investigación. La argumentación aquí es que la injusticia epistémica, que generalmente comienza con casos aparentemente "menores" de prejuicio de identidad, podría filtrarse en la práctica real de P4wC. Partiendo de Fricker, las variadas formas de injusticia epistémica se hacen explícitas cuando las prácticas epistémicas se enmarcan dentro de las circunstancias sociales concretas donde se cruzan el poder, el privilegio y la autoridad, lo cual es más observable en entornos escolares. En relación con esto, a pesar de las mejoras pedagógicas que ofrece $\mathrm{P} 4 \mathrm{wC}$, algunas formas de prejuicio de identidad que prevalecen en las aulas tradicionales pueden persistir y afectar particularmente a los niños y niñas que se identifican con grupos sociales estereotipados negativamente. Por lo tanto, es crucial prestar atención a la realidad de la injusticia epistémica y los posibles lugares donde podría surgir potencialmente en la COI. A partir de mi experiencia en $\mathrm{P} 4 \mathrm{wC}$, muestro que el prejuicio de identidad puede provenir de las intersecciones de roles y posiciones de los participantes en un diálogo filosófico. Estas intersecciones pertenecen a las relaciones epistémicas entre el maestro en $\mathrm{P} 4 \mathrm{wC}$, los alumnos y la propia $\mathrm{P} 4 \mathrm{wC}$. Concluyo que el prejuicio de identidad surge circunstancial y/o sustancial en los estudios y en la práctica de $\mathrm{P} 4 \mathrm{wC}$.

palabras clave: injusticia epistémica; injusticia testimonial y hermenéutica; perconcepto; comunidad de investigación; filosofía para / con niños 
mapping identity prejudice:

locations of epistemic injustice in philosophy for/with children

\section{introduction}

Prejudice is an unjustified adverse attitude towards a particular social group (COHRS \& DUCKITT, 2012; GOLU, 2013). It is often fueled by widespread negative stereotypes that are overgeneralized to the members of that group without a reasonable basis or even a direct experience with them. In schools, prejudice can potentially impede students' academic, social, and psychological well-being (STEELE, 1997; BENNER, CROSNOE \& ECCLES, 2014). Over time, prejudice causes systemic discrimination, thereby making it difficult for students identified with negatively stereotyped groups to pursue their educational potentials.

Recent discourses on Social Epistemology tackle the phenomenon of epistemic injustice in which a person is wronged on the basis of his/her capacity as a knower (FRICKER, 2007; MEDINA, 2017). Children, taken as a social domain, become subjects of epistemic injustice due to a prejudice against their young age and lack of experience (MURRIS, 2013; SCHÜES 2016; BURROUGHS \& TOLLEFSEN, 2016). This happens when what they have to say is systematically and unreasonably dismissed because they are children. Accordingly, their questions, views, and experiences are given low epistemic credibility, causing adults to discredit their capacity as sources of knowledge (BAUMTROG, 2018).

Despite the notable improvements $\mathrm{P} 4 \mathrm{wC}$ offers in addressing the deficits of traditional models of education, is it possible that epistemic injustice would still occur in a Community of Inquiry? This is the central question this article hopes to address. The assumption here is that transforming a class into a COI does not happen immediately. Some old habits and practices prevalent in a traditional classroom would continue to persist despite the appropriation of the principles and procedures of inquiry and collaborative dialogue. Hence, depending on the circumstances, a COI 
mapping identity prejudice: locations of epistemic injustice in philosophy for/with children

has to address the issue of identity prejudice by constantly paying attention to the possible locations where epistemic prejudice potentially occurs.

This article is divided into three parts. The first part consists of a literature review on epistemic injustice within $\mathrm{P} 4 \mathrm{wC}$. It includes a short discussion on the nature, types and effects of epistemic injustice. The second part tackles how children become subjects of epistemic injustice, which is followed by a discussion of the dimensions of epistemic injustice within the school setting. The third part is a narration of five observations from my experience where some forms of identity prejudice surfaced. From these observations, I conclude that identity prejudice, which can lead to epistemic injustice, arise circumstantially, and/or substantively in P4wC theory and practice.

\section{epistemic injustice in p4wc: a brief literature review}

It is not farfetched to suppose that the pervasiveness of prejudice and negative stereotypes, particularly in schools, had made an impact on Matthew Lipman and the early proponents of the program. In Thinking in Education, he stresses that "critical thinking is hostile to all stereotyping; and since such stereotyping is the mechanism through which biased thinking operates, to all prejudice" (LIPMAN, 2003, p.220). For him, prejudice is a product of a mental mistake or a lack of sophisticated cognitive skills to resist or counter its various forms. Education, for this reason, should aim to impart to students the skills for better judgment since teaching them how to think well addresses this cognitive lack. Critical and reflective thinking ought to be exercised and developed as it prepares children to recognize bias, prejudice and selfdeception, as well as to protect them from being subjected to it (Ibid., p.26, p.273). He also recognizes that in cases of prejudice, "it is difficult to correct the matter simply by direct communication or instruction" (Ibid., p.184). This implies that teaching children about prejudice didactically may not necessarily lead to positive changes in behavior. On this note, Guin (1992) observes that it is "unlikely that admonitions and exhortations will have much effect, especially with children already schooled in 
intolerance" (p.141). What is needed is a pedagogy that immerses children in an intellectually challenging yet nurturing environment where rational procedures and democratic values are not only talked about but, most importantly, applied and practiced. The Community of Inquiry is one such pedagogy that fosters the habituation of virtuous mental attitudes, which students can internalize in the long run.

Several P4wC practitioners call for an increased awareness of the problem of prejudice and epistemic injustice. Drawing from the ideas of Fricker, Karin Murris (2013) argues that "credibility deficit is related to age in that being of a particular age has a significant impact on how much credibility a hearer affords a speaker, and when and how s/he is silenced systematically" (p.249). While Fricker's analyses of the phenomenon of epistemic injustice are applied mainly to issues related to gender and race, Murris draws attention to the prejudice committed to children - also known as ageism - which can weigh on a child's psychological and emotional well-being, potentially impeding her intellectual and emotional growth. This implies that repeated experience of identity prejudice harms the educational development of a child and her capacity to make sense of her own experiences independently. In this regard, she challenges those involved in the education of the young to develop the virtue of epistemic justice, which involves "resisting and normalizing discourses about child and hearing child's unique voice" (Ibid. p.257).

Arie Kizel (2016) also addresses the problem of structural epistemic injustice, which for him creates situations where children are unable to express their identity and narratives. He observes that even in the context of a philosophical dialogue, there are children who feel constrained to express their thoughts and feelings because their respective narrative "does not accord with that of the dominant national narrative" (p. 17). This follows that despite the presuppositions of objectivity and neutrality, a community of philosophical inquiry may still be governed by dominant and exclusivist meta-narratives. This is a crucial insight since it shows that a COI can never be neutral. Kizel, however, asserts that communities of philosophical inquiry 
mapping identity prejudice: locations of epistemic injustice in philosophy for/with children

can provide a discursive space in which participants can freely and actively express their otherness. He calls this theoretical model "enabling identity," which is aimed to address the pervasiveness of meta-narratives of the mainstream society, thereby allowing spaces where marginalized voices are heard, and unique identities expressed (p. 20).

Moving forward, Jana Mohr Lone (2018) explains the effect of not listening seriously to children on our shared hermeneutical resources. While maintaining that epistemic injustice can have a detrimental impact on the epistemic abilities of children, she also thinks that "the credibility deficit experienced by children results in a lack of access by adults to important sources of knowledge and new perspectives" (LONE, 2018). In other words, the epistemic harms directed particularly at children also affect adults in that undermining their unique narratives results in an impoverished understanding of the world. Children's positionality as 'newcomers' could provide us with valuable insights from their unique perspectives, which is no longer accessible to an adult. She adds that children's perspectives can help us to "think about philosophical questions - about justice, ethics, friendship, etc. - in new and fresh ways" (Ibid.).

Moreover, Reed-Sandoval and Sykes (2017) argue for an increased sensitivity towards the impact of positionality in the context of a COI as it affects how a child discovers meaning from her experiences of the world. Similar to Kizel's observation, some children are "positioned such that their lived experiences and philosophical questions are socially under-valued and unrecognized" (REED-SANDOVAL \& SYKES, 2017, p.220). Despite the democratic values fostered in a COI, it is not easy for these children to make themselves heard in a dialogue. Thus, even if $\mathrm{P} 4 \mathrm{wC}$ is already an improvement from the traditional models of education, it may still "underserve, and perhaps even marginalize, children who suffer epistemic injustice" (Ibid.). For this reason, they recommend taking positionality seriously in $\mathrm{P} 4 \mathrm{wC}$ research and practice in order to avoid being uncritical and complicit towards the epistemic authority of the status quo, which tend to dominate in a dialogue. 
Meanwhile, there are other notable works that also tackle, albeit indirectly, occasions of epistemic injustice in the context of $\mathrm{P} 4 \mathrm{wC}$ research and practice. Rainville (2001) makes a critical observation concerning indigenous students who have been exposed to prolonged institutional marginalization. He argues that "even when we set democratic goals within the classroom, children are still subject to the subtle influences and pressures which shape and constrain all of [their] lives" (p.69). $\mathrm{He}$ is wary that the supposedly neutral approach of $\mathrm{P} 4 \mathrm{wC}$ pedagogy may reinforce the marginalization of children coming from indigenous communities who participate in a COI. This is echoed by Madrid (2008), who reports a crucial insight regarding the transcultural applicability of the dialogical procedures and key concepts in P4wC based on her experience with native Oaxacan children. She poignantly notes that

Sometimes we think that we are behaving in a democratic manner, but from another point of view, we are arrogant, disrespectful and ignorant, and we end up in unwitting complicity with the forces of oppression and inequality. Are we naïve, and do we have the right to be naive in communities with a history of oppression? We need to realize and remain aware of the political implications of the discourse model we are offering, otherwise we will be like religious missionaries-changing forms of life under a profoundly mistaken assumption (p.134).

This literature review, though not exhaustive, shows that tackling the various forms of prejudice in the context of $\mathrm{P} 4 \mathrm{wC}$ is a critical aspect of its scholarship and practice. Most of these works imply that $\mathrm{P} 4 \mathrm{wC}$ is not a 'magic wand' that can dramatically dissolve all the problems related to the education of children. It certainly has its limitations, both theoretically and practically. Nevertheless, it stands as a better alternative especially in addressing the problem of epistemic injustice, not least because it is built on the fundamental recognition that children are thinkers, a claim that carries an imperative for adults to listen and show epistemic trust to what children have to say. 
mapping identity prejudice: locations of epistemic injustice in philosophy for/with children

\section{epistemic injustice: testimonial and hermeneutic}

Epistemic injustice is a type of harm done by an individual towards another person, which unfairly and unreasonably prevent her from actively exercising her intellectual abilities, potentially impeding her self-development. In her 2007 book, Miranda Fricker explains that an epistemic injustice occurs when someone is wronged based on her capacity as a knower (FRICKER, 2007, p.1). This is predicated on the assumption that every human individual possesses an inherent ability to make sense of her experiences of the world, and the capability to convey knowledge to others. Central to it is the recognition of every person's right to know and communicate information without being subjected to prejudice or bias.

The discourse on epistemic injustice foregrounds the inherent sociality of human epistemic practices. It departs from the classical epistemological approaches that presuppose an abstracted understanding of the subject of knowledge, independent of the social conditions surrounding it. This means that situating the knower, the known, and the process of knowing within its social context makes possible the articulation of the complex intersections of power, privilege, and authority operating within various social institutions and groups. It follows that taking the basic epistemological elements as interdependent and inextricably linked to the context, especially to the positionalities of the persons involved, exposes the ethical features of these epistemic interactions.

Testimonial Injustice is a subcategory of epistemic injustice, which occurs when a "prejudice causes a hearer to give a deflated level of credibility to a speaker's word" (Ibid., p. 1). This is the most common form of epistemic injustice in which the hearer's prejudice unfairly accords a speaker less credibility as a giver of knowledge based on some aspects of her identity, such as age, gender, race, ethnicity, and socio-economic status. This happens when one does not trust what the other person says as much as one should due to some assumed prejudice towards the speaker's identity. Fricker characterizes this as "identity-prejudicial credibility deficit" (Ibid., p.4). It must be noted that a testimonial injustice is not merely an "innocent error" as it "involves not 
only a kind of intellectual carelessness, but also harmful and immoral attitudes" (SHERMAN AND GOGUEN, 2019, p.3). This is why epistemic injustice is ethically and epistemically wrong. On the other hand,hermeneutic injustice is another subcategory in which the epistemic harm arises due to an absence of conceptual and linguistic resources resulting in a disproportionate treatment of some individuals or groups. Fricker explains that this stems from "a gap in collective hermeneutical resources - a gap, that is, in our shared tools of social interpretation - where it is no accident that the cognitive disadvantage created by this gap impinges unequally on different social groups" (FRICKER, 2007, p.6). In other words, the knower's social situation causes and even sustains an absence of collective meanings, thereby depriving her of making sense of and articulating an objectively unjust experience. At the core of hermeneutic injustice is the fact that some individuals and groups are rendered voiceless in the collective process of meaning-making (MEDINA, 2017). This is imminent in societies where members of various minority groups are denied the "opportunity to articulate their experiences, be heard by others, and reach new collective understandings" (SHERMAN \& GOGUEN, 2019, p.6).

A society without prejudice and negative stereotypes is obviously a utopian aspiration. In an imperfect society with imperfect individuals, prejudice is simply unavoidable. However, there are forms of prejudice that cause a broad and enduring impact on certain people. These are unreasonable and unfounded prejudgments that affect not only one aspect of a person's identity, but also in the other dimensions of her social life. Thus, when a negative stereotype affects not only epistemically, but also educationally, sexually, religiously and politically, the said prejudice is no longer a mere 'simple' and isolated case of discrimination, but a case of epistemic injustice. It is, therefore, essential to pay attention to epistemic injustice as it can damage a person's pursuit for healthy development of self. Just as social inequality results in the exclusion of some social groups from opportunities to develop their potentials and live good lives, epistemic injustice, likewise, causes some social groups to be deprived of freely exercising their epistemic abilities and actualizing their epistemic 
mapping identity prejudice: locations of epistemic injustice in philosophy for/with children

potentials sans fear, prejudice, and intimidation. Among these social groups that are susceptible to epistemic injustice are children. I will explore this in the next section.

\section{children as subjects of epistemic injustice}

Children become subjects of epistemic injustice when adults dismiss what they have to say (even if it is true) because they are children. In these situations, the lack of epistemic trust accorded to a child stems from a prejudice based on age, which inevitably places them at a disadvantaged position in the knowledge community. In other cases, these prejudices are compounded when the other aspects of a child's identity (e.g., ethnicity, language, religion, and gender) are also used as bases for the dismissal of her testimony. Schües argues that the "well-being of children is a mirror of the state of justice in the world" (2016, p.156). That children should be listened to without prejudice is linked to the claim that their lives and the unjust structures surrounding them manifest the kind of society they live in. What this implies is that the epistemic injustice children endure is not apparent insofar as the prejudice towards them is deeply rooted, and in many ways hidden, within the normative social structures and institutions. Ironically, among the social institutions where children experience identity prejudice are schools, which supposedly function as centers for the development of humane values, such as equality, freedom, and justice.

\section{epistemic injustice in the school setting}

To sketch the various ways in which students (and also teachers) are subjected to identity prejudice, I follow Kotzee (2017) in determining the possible dimensions where epistemic injustice may arise. These dimensions pertain to the epistemic relationships of the teacher, students, the curricula, and the school in general.

The first dimension points to the level of credibility assigned to learners. This manifests when school authorities assign an unreasonably low epistemic credit to students owing to a prejudice or a negative stereotype attached to their social identity. For instance, epistemic harm is done to a student when teachers 
unreasonably discredit the veracity of her testimony because she is just a 'child' or simply a 'student.' The second dimension pertains to the implicit criteria teachers use in crediting particular learners. This occurs when teachers inflate their credibility judgment towards the views of students who are perceived to belong in the dominant and privileged groups. Such inflated judgment may be based on a particular student's physical features, economic status, intelligence, language, and social influence in the classroom. The third dimension touches on what the teachers teach in the class. The content and method of a prescribed curricula can be a site for epistemic injustice, especially when the process of creating them systematically renders invisible and inaccessible the salient knowledge about the less privileged social groups. The fourth dimension refers to the criteria of admitting students to particular courses of study. When an individual is denied admission in a course or a school because of her background, say, sexual orientation or religion, she is wronged as a knower who possesses the basic right to education. The fifth dimension points to the process of choosing who gets accepted as teachers and scholars. This occurs when a school avoids fostering diversity in its teaching and non-teaching ranks by systematically denying access to prospective teachers and scholars from marginalized groups. The sixth dimension pertains to the ways students give epistemic credit to teachers. Here, epistemic injustice arises when students treat certain teachers with less credibility and authority due to their social background. This happens mostly to teachers who are positioned in a less privileged status in the society, such as those who are graduates of an unfamiliar university, members of minority groups (e.g., LGBTQ+), and those who do not share the dominant religion. Lastly, the seventh dimension refers to the criteria students use to credit (or discredit) the epistemic abilities of other students. This manifests, for instance, when some students assign an unreasonably deflated epistemic status to their fellow classmates owing to a widespread negative stereotype associated with them.

These dimensions provide us with a 'map' where we can locate possible occasions of identity prejudice in the COI to catch potential cases of epistemic 
mapping identity prejudice: locations of epistemic injustice in philosophy for/with children

injustice. In the school setting, spotting identity prejudice is rather tricky as it does not always appear as blatant as when it happens outside the school. Some prejudice appear 'normal,' such as, when a well-meaning teacher religiously follows a curriculum without noticing its underlying bias against other forms and sources of knowledge, or when a school rejects applications from particular students not because they failed the entrance exam but because of their other backgrounds, such as religion or sexual orientation. School authorities, therefore, ought to have an acute awareness of how identity prejudice may leak into their school ethos and policies.

\section{locations of identity prejudice in p4wc}

In this section, I outline five locations/intersections where identity prejudice manifested in my $\mathrm{P} 4 \mathrm{wC}$ experiences. I have to note that these observations do not necessarily constitute epistemic injustice. They are, however, instances of identity prejudice, which either lead or, in other cases, reinforce an already existing testimonial and hermeneutic injustice. The salient point here is that these forms of identity prejudice cause serious epistemic harms when unchecked or tolerated over a period of time.

identity prejudice occurs when a p4wc teacher unwittingly assigns a low credibility judgment of children's ideas

This first observation involves myself as a neophyte P4wC teacher who unwittingly assigned a low credibility judgment to the ideas shared by two 5th-grade indigenous students. In one of our dialogues, the question the class chose to tackle was: 'What are the characteristics of a good leader?' The dialogical inquiry led to a sharing of wonderful ideas. However, one student dared to share a slightly 'off' answer. For him, a leader "should carry guns and kill those who do not obey." His answer caused mixed reactions from the group, and it encouraged another boy to add: "a leader should be an authoritarian!" Mindful that these non-standard answers could stimulate the inquiry further, I encouraged them to discuss their answers, 
which eventually ended with a consensus that rejected their propositions. Quietly in my mind, however, I did not give their answers due credence and, in fact, mentally categorized them as childish responses. Such answers must have been influenced by watching too many action movies, I thought. Though I did not dismiss their answers during the inquiry, I gave them a deflated view because these boys seemed innocent and were merely expressing some trivial ideas. Put differently, they simply did not know what they were talking about. Later that day, I met one of the boys' mother and mentioned to her what her son said in the class. She confided to me that, for some time, her son studied in a 'school' situated in a very remote part of their town that is believed to be an area where some members of the New People's Army ${ }^{2}$ were based. According to what her son told her, it was common for him to see adult men carrying guns while talking to their teachers and elders in the community. These scenarios must have instilled in the young boy's mind the image of a leader who asserts authority using the might of a gun. Upon hearing this, it became clear to me that my prior idea of him as an 'innocent boy with childish ideas' was a stereotype I unwittingly assigned to him because of his age and appearance.

While my naiveté did not necessarily constitute an epistemic injustice, it was nevertheless an occasion of identity prejudice leading me to treat his idea with low epistemic credit. In other words, I heard him but failed to seriously listen to his point owing to my unchecked implicit assumptions. I could only imagine how often testimonies like these from young students are not given proper attention even among the most well-meaning teachers. What if a student is trying to communicate an ongoing abuse, but her manner of expression makes it seem unbelievable? Or what if a student attempts to share an unsettling experience, but the context where it is told makes it sound less serious? The point here is that epistemic injustice stems from seemingly 'trivial' and 'inconspicuous' cases of identity prejudice in which teachers downplay the importance, or in other cases the urgency, of a child's testimony. When these moments are tolerated and prolonged, they would inevitably

${ }^{2}$ The New People's Army (NPA) is the armed group of the Communist Party of the Philippines. 
mapping identity prejudice: locations of epistemic injustice in philosophy for/with children

compound, which in the long run, potentially damage a student's perception not only towards her epistemic abilities but her overall sense of self.

identity prejudice is probably taking place in a class when some children feel deterred to engage in the inquiry

This second observation shows that even within the context of a COI, children feel deterred to engage in the dialogue because they are impaired either positionally or intellectually. If we look at the COI from the vantage of power and privilege, we see a hierarchy of epistemic relations between those who have more epistemic power or influence, and those who have less. Because of such hierarchy, some students are constrained to participate because they think they have less epistemic power in relation to the other students in the COI. In other words, these children are hesitant to participate because they are impaired positionally. In these cases, prejudice is already operating in the class and, to some extent, already internalized. Santoro and Kumar (2014) point out that in some cases, children "internalize their condition of deprivation, thus failing to interpret it as a case of injustice" (p.2). This is true especially among students who have experienced repeated cases of identity prejudice. Despite being fully aware that their experience is objectively wrong, their environment normalizes the prejudice, thereby forcing them to accept it as part of their everyday lives. Even when there are no explicit expressions of negative stereotypes within the COI, some of these children cannot see beyond their perceived inferior positionalities, consequently deterring them from contributing to the dialogue.

Meanwhile, there are cases when a student is unable to participate in a sustained rational dialogue because she is impaired intellectually. In the school where I taught $\mathrm{P} 4 \mathrm{wC}$, there is a 12-year old female student who is well-known in the campus for being stuck in third grade. One time, she joined our P4wC class, showed interest in the dialogue, but never said a word. Curious about her, I asked her teacher and the principal who explained to me that she has a 'unique' condition. For me, this 
meant only one thing: she has special educational needs. As I found out later on, there are actually two of them who have a learning disability. The other is an 18-year old boy in fourth grade who also has an undiagnosed special need. In a P4wC class, these students may not necessarily feel deterred to engage in the dialogue despite their condition; however, the chances of them being subjected to social stereotypes (especially since they are mixed with the other students) can cause further damage to their growth and development. ${ }^{3}$

Being impaired positionally or intellectually can discourage some children from engaging actively in philosophical dialogues. For this reason, it is essential to be sensitive towards how prejudice already operate in the class even before they are exposed to $\mathrm{P} 4 \mathrm{wC}$. Ignoring these identity prejudices could reinforce hermeneutic injustice that cripples their ability to make sense of their own experiences. When students start to think that it is 'normal' to experience bullying and discrimination regularly, it only shows that there is a considerable gap in their hermeneutical resources, thereby disabling them to see and confront these epistemic harms objectively.

identity prejudice occurs when children assign low epistemic credit to what their less privileged classmates have to say

Epistemic injustice may also happen between children. Usually, this occurs when a child rejects her classmate's view based on her social background, e.g., gender, economic status, or academic standing in the class. This fourth observation describes how children assigned a deflated credibility judgment towards their less privileged classmates, not because their ideas were irrelevant or wrong, but because deeply established negative stereotypes influenced their views of them.

\footnotetext{
${ }^{3}$ Unfortunately, in the Philippines, the Department of Education has much to improve in its program for children who have special educational needs. Most low-income families cannot send their children to schools that can specifically address their condition. This is why children from poor families are sent to regular schools, consequently increasing the chances of them being subjected to repeated prejudice based on their condition.
} 
mapping identity prejudice: locations of epistemic injustice in philosophy for/with children

On one occasion, to facilitate an ethical thinking exercise, I appropriated a thought experiment ${ }^{4}$ in which they have to choose a limited number of people who can safely stay for a year inside a safe house while the earth supposedly recovers from a huge catastrophe. Their votes will decide who will be saved according to the social roles they deem important in the future. Each student got a random piece of paper (which I prepared) that assigned them a particular social identity. Before the voting started, they had to describe and explain to the class their imagined identities to convince their classmates of the importance of their supposed role in society. Interestingly, the identities who were chosen to be saved were: an older man, a president, a librarian, a mother, an engineer, a driver, and a criminal. This activity was a helpful exercise that encouraged them to decide independently and provide reasons for their decisions. However, what was more interesting for me was the fact that some of them downplayed what their other classmates said, not according to the reasons they provided, but based on the manner of describing their supposed identity. Their tone, language, choice of words, and even their gestures were given more weight than the reasons offered. Consequently, those children whose manner of expression was deemed 'acceptable' were more favored than those who were not able to express themselves well. Moreover, some of them were 'judged' based on their position in the class, as in the case of the student who picked the identity of a 'criminal' but was positively selected by the majority because he was popular. In other words, most of them voted according to who their classmate actually is to them, rather than on each other's imagined identity in the thought experiment. As a result, those who are not well-favored in the class received fewer votes even if they had picked an objectively important social identity.

Meanwhile, I observed that some well-meaning students also felt constrained to reasonably participate in the activity due to the widespread prejudice attributed to their less privileged classmates. These students who are conscious of the effects of the

\footnotetext{
4 This activity is patterned from the movie "After the Dark" (2013) which can be viewed as a simulation of Rawls' idea of the 'veil of ignorance' and 'natural lottery'.
} 
negative stereotypes assigned to their vulnerable classmates also felt hampered to address the ongoing prejudice because they were only few and outnumbered. For a child, it seemed convenient to just get along with the majority than to stand against them. Beeby (2019) articulates a similar problem when she asks: "What do we do when more or less well-intentioned knowers, who do their knowing under the influence of unjust or otherwise epistemically corrosive social structures and institutional frameworks, end up perpetuating such structures?" (p.233). Applied to my context, her question has two implications: a) not all students tolerate the negative stereotypes assigned to their less privileged classmates and, b) there are deeply-rooted negative stereotypes which, even for a reflexive and well-intentioned student, are too difficult to address.

children taking $p 4 w c$ classes may be prejudiced owing to a collective interpretation of philosophy as a 'dangerous' subject

In this fourth observation, the potential epistemic harm occurs in societies where the term 'Philosophy' is assigned a pejorative meaning or is socially understood as a 'dangerous' subject. In the context of my $\mathrm{P} 4 \mathrm{wC}$ practice, the identity prejudice is caused by people who maintain a negative bias towards Philosophy in general and, by extension, towards those who study it.

During my first P4wC class, the well-meaning principal curiously asked: what do you teach in a Philosophy class? In my previous experiences, when this question is asked by someone who has a little background of the subject, it sometimes implies that the person's intent is not to know my answer any more than to express his presumptions about the term 'philosopher.' Before I could give a quick reply to his question, it did not take long for him to mention the pejorative interpretation of 'pilosopo' (philosopher) and its local trope 'Pilosopong Tasyo' from Jose Rizal's novel, which equates a philosopher to a fool. ${ }^{5}$ His follow-up question was as loaded as the first: Are you teaching children to become philosophers? In this English translation,

\footnotetext{
${ }^{5}$ From the novel Noli Me Tangere (Touch Me Not) written by Dr. Jose Rizal, Philippine's national hero.
} 
mapping identity prejudice: locations of epistemic injustice in philosophy for/with children

a non-Filipino may not see any problem with such a seemingly neutral question. However, in its original articulation in my dialect, the question actually carries a host of assumptions, mostly disapproving. In the Philippines, 'pilosopo' could mean many things to different Filipinos. This term calls to mind an image of a sophist who is good at rhetorical argumentation without any concern for the truth. It could refer to a person who disrespectfully talks back at someone in authority, such as a parent. It could also represent someone who uses humor (often nonsensical) to get out of a confrontation or to trump a dialogue. Among my well-meaning friends, for instance, some could not contain their worry that exposing young children to philosophical questions and topics at an early age might be inappropriate, and to some extent, dangerous. Their notion of philosophical thinking is understandably predicated on a crude perception of philosophical thinking that is devoid of respect and ethical responsibility. These interpretations of 'philosophy' and 'philosopher' infuse a legitimate worry among Filipino adults who think that children might be encouraged to challenge societal beliefs and family traditions disrespectfully and uncaringly.

By and large, young Filipinos do not have yet preconceived biases towards Philosophy in general. However, Filipino adults surrounding them, viz., parents, teachers, and those who assume disapproving interpretations of the term 'pilosopo' may exert undue prejudice to those who will participate in $\mathrm{P} 4 \mathrm{wC}$ classes. Likewise, it causes a considerable gap in the hermeneutic understanding of Philosophy in general, thereby blocking Filipino children out from discovering its valuable role in shaping the collective consciousness of a society.

hermeneutic injustice follows when the ' $p$ ' in $p 4 w c$ excludes other modes of understanding and of doing philosophy

This fifth observation refers to my observation concerning the theoretical foundations of $\mathrm{P} 4 \mathrm{wC}$. I notice that little attention has been given to the integration of indigenous epistemologies and other non-western philosophies in the conceptual and methodological landscape of $\mathrm{P} 4 \mathrm{wC}$. One reason for this lack of attention, I think, is 
the fact that when Philosophy is appropriated in non-western cultural arenas, it usually comes with a western epistemic 'baggage' that naturally clashes with and usually dominates over the underlying epistemology of the locale. Accordingly, in assuming the applicability of $\mathrm{P} 4 \mathrm{wC}$ theory and practice in different cultural settings, one inevitably assents to the presupposition that the 'Philosophy' in $\mathrm{P} 4 \mathrm{wC}$ is generalizable in various contexts. It follows that its methodology, likewise, has a generalizable feature which can transcend space and time. Taken in this sense, Philosophy assumes a hegemonic character that leaves unchallenged the idea that philosophical thinking can be exercised regardless of the situated-ness of knowers and their rootedness on culture, language, beliefs, and traditions. Philosophy is obviously integral in $\mathrm{P} 4 \mathrm{wC}$, but before one deploys it in actual practice, there are at least three questions that need to be asked: Whose Philosophy? What kind of Philosophy? And for whom?

My claim here is that 'Philosophy' is universal insofar as it pertains to the fundamental human ability to make sense of the world and to search for the truth. However, 'Philosophy' is not universal if it is narrowly reduced to the ideas and methodologies put forward by western philosophers. It is important to mention here that $\mathrm{P} 4 \mathrm{wC}$ has already been appropriated and practiced in the different parts of the world, including several non-western countries. I do not mean to imply that it is confined within western theories and methods. Nevertheless, as a P4wC practitioner/researcher who is from a non-western society, I cannot help but rely on western literature to support my practice due to the dearth of materials and resources in my local context. This does not necessarily translate to a 'bad practice' since a comprehensive theoretical grasp and practical exposure to the various expressions of $\mathrm{P} 4 \mathrm{wC}$ are integral in a robust research. The point here is that it is incumbent upon a non-western practitioner like myself to diversify my resources and cultivate alternative views that apply to my context. Concretely, this means choosing locallyproduced literature that is relevant and interesting to children. In my case, I broaden 
mapping identity prejudice: locations of epistemic injustice in philosophy for/with children

my P4wC repertoire with various eastern literature ${ }^{6}$, which also stimulate critical, caring, and creative thinking.

Moreover, such diversification is not only limited to merely adding other sources of literature to be utilized in the dialogues. Rather, it also entails exploring other ways of carrying out a philosophical reflection. This means expanding the modes and criteria for philosophizing to include other equally legitimate epistemologies. Indigenous knowledge, for instance, is an abundant reservoir that can expand the theoretical foundations of the program. For instance, a presentational epistemology, which is an undercurrent in most indigenous forms of knowledge, provides a counterweight to the representational epistemology dominant in most P4wC practice. In this approach, the child discovers that epistemic agency does not solely proceed from her or tied to her but shared with her and the community. This 'indigenized' philosophical inquiry challenges the assumption that the world can only be discovered and conquered discursively and intellectually (ELICOR, 2019).

In relation, a limited understanding of Philosophy could lead to epistemic injustice whereby a Filipino child's ideas are not seriously taken because 'it is not philosophical enough.' This usually happens when only western criteria are used to evaluate local ways of thinking. Whether or not this indigenized approach can be significant in western contexts is beyond the scope of this article. My suggestion, however, is that diversification of the content and methodology of $\mathrm{P} 4 \mathrm{wC}$ avoids espousing a narrow understanding of Philosophy in $\mathrm{P} 4 \mathrm{wC}$, thereby expanding the interpretative resources concerning its nature and practice. Accordingly, it avoids a "gated" community of inquiry and resists privileging the dominant patterns and criteria for philosophical thinking, which means including as many epistemologies as possible (CHETTY, 2018).

\footnotetext{
${ }^{6}$ I integrated selected stories from local indigenous communities, and some passages from Chinese and Buddhist Philosophies.
} 


\section{conclusion}

In this article, one of my aims is to suggest that epistemic injustice, which usually begins from seemingly 'trivial' cases of identity prejudice, can potentially leak into the actual practice of $\mathrm{P} 4 \mathrm{wC}$. My five observations show that identity prejudice may arise at the various intersecting points of the different roles and positionalities of the participants in the COI. These intersections/locations pertain to the epistemic relationships between myself as a $\mathrm{P} 4 \mathrm{wC}$ teacher, the students, and the foundations of P4wC. While these observations could mean that I was yet unsuccessful in applying the principles and fostering the values embedded in the program, they also highlight the fact that turning traditional classrooms into communities of inquiry necessarily involves a transformational process. Just like an athlete who needs to continually practice in order to be better at a sport, building a COI, likewise, requires constant practice in establishing philosophical dialogues that address prejudice and, in the process, internalize more caring thinking without losing its critical import (SHARP, 2014). It would be naïve of me to think that a class dramatically transforms into a COI in its first few philosophical dialogues. Some elements of the traditional classroom culture would continue to persist despite the appropriation of the principles and procedures of inquiry. Of course, the goal is to foster a community that has a keen sense of epistemic virtues, but while in the process, it is important to be sensitive to these intersections where identity prejudices would potentially surface.

Based on these five observations, identity prejudice in $\mathrm{P} 4 \mathrm{wC}$ either stems circumstantially and/or substantively. The first four observations mentioned above are rooted in the circumstantial factors that are distinct in a particular context, while the fifth observation is rooted substantively in the dominant understanding of the ' $\mathrm{P}$ ' in $\mathrm{P} 4 \mathrm{wC}$.

In the first four observations, identity prejudice arose from the circumstantial factors specific to the actual context of the philosophical dialogues. The circumstances surrounding them were all relevant to my $\mathrm{P} 4 \mathrm{wC}$ practice but not essential to $\mathrm{P} 4 \mathrm{wC}$ itself. They are all incidental factors, dependent on the particularities where I 
mapping identity prejudice: locations of epistemic injustice in philosophy for/with children

conducted my practice. For instance, the pejorative interpretations of the terms 'philosophy' and 'philosopher' may not necessarily apply to other cultural contexts, thereby confining such observation only within my context. Is it necessary to pay attention to the circumstantial factors surrounding the COI? It may be well to recall that the framework for conceptualizing the nature of epistemic injustice focuses on the socially situated account of epistemic practices. Epistemic injustices, which are usually implicit within the social structures in the society, are made explicit when our epistemic practices are framed within the concrete social circumstances where power, privilege and authority intersect - which is observable in school settings. In this connection, a feasible way of spotting identity prejudices is to begin looking critically at the particular and incidental elements that could potentially induce them. It is, therefore, essential to ask: What are the socio-cultural conditions underlying children's position in the COI? What are the deeply ingrained negative stereotypes prevalent in the immediate community? Are there cases whereby students buy into the negative stereotypes? How does a P4wC teacher's positionality affect the dialogues? What are the underlying views of the term 'Philosophy' from the immediate community or society? These are some of the questions that provide a socially situated description of the epistemic interactions within the COI, which are essential in exposing their ethical dimension.

My fifth observation shows that identity prejudice may also arise from certain substantive factors that are directly connected to $\mathrm{P} 4 \mathrm{wC}$ because these have something to do with its core theory. My assumption here is that there is an implicit hermeneutical lacuna or a gap in the interpretative resources in the dominant understanding of what Philosophy means in P4wC. My claim here is that the presuppositions in $\mathrm{P} 4 \mathrm{wC}$ could be missing out from what other less dominant philosophies can contribute to its conceptual landscape. This is predicated on the premise that there are alternative epistemologies that are as equally legitimate as the standards of philosophical thinking currently leading $\mathrm{P} 4 \mathrm{wC}$ scholarship and practice. One such epistemology can be inferred from the various forms of indigenous 
knowledge, which have a lot to contribute not only to $\mathrm{P} 4 \mathrm{wC}$ but to a plethora of socio-economic, ecological, and cultural issues affecting the entire planet. Thus, as

P4wC scholars and practitioners, we begin to rethink the ways we normally carry out philosophical dialogues, and perhaps welcome the possibility of integrating nondominant forms of knowledge in our fundamental assumptions.

\section{references}

Baumtrog, Michael. “Navigating a Necessary Inequality: Children and Knowledge-Based Injustice," in Alternative Routes: A Journal of Critical Research, Vol. 29, 2018, pp.294-306.

Beeby, Laura. "Epistemic Justice: Three Models of Virtue," in The Routledge Handbook of Virtue Epistemology, ed. Heather Battaly, New York: Routledge, 2019.

Benner, Aprile, Crosnoe, Robert and Jacquelynne Eccles. "Schools, Peers, and Prejudice in Adolescence," in Journal of Research on Adolescence, 25 (1), 2014, pp.173-188.

Burroughs, Michael D. and Deborah Tollefsen. "Learning To Listen: Epistemic Injustice and the Child," in Episteme, 13, 3, 2016, pp. 359-377.

Chetty, Darren. "Racism as 'Reasonableness': Philosophy for Children and the Gated Community of Inquiry," in Ethics and Education, 2018, pp.39-54.

Cohrs, J. Christopher \& John Duckitt. "Prejudice, Types and Origins of," in The Encyclopedia of Peace Psychology, First Edition, edited by Daniel J. Christie, UK: Blackwell Publishing Ltd., 2012, pp.1-7.

Elicor, Peter Paul. "Philosophical Dialogues with Indigenous Children: An Attempt to Integrate Indigenous Forms of Knowledge in Philosophy for/with Children," in Childhood E Philosophy, Vol.15, June 2019. pp.1-22.

Fricker, Miranda. Epistemic Injustice: Power $\mathcal{E}$ the Ethics of Knowing. New York: Oxford University Press Inc., 2007.

Golu, Florinda. "Prejudice and Stereotypes in School Environment: Application to adolescence," in Procedia - Social and Behavioral Sciences, 78, 2013, pp.61-65.

Guin, Philip. "Countering Prejudice with Counterexamples," in Studies in Philosophy for Children: Harry Stottlemeier's Discovery, edited by Ann Margaret Sharp \& Ronal F. Reed, Philadelphia: Temple University Press, 1992, pp.135-143.

Kizel, Arie. "Enabling Identity: The challenge of Presenting the Silenced Voices of Repressed Groups in Philosophic Communities of Inquiry," in Journal of Philosophy in Schools, 3, 1, 2016, pp. 16-39.

Kotzee, Ben. "Education and Epistemic Injustice," in The Routledge Handbook of Epistemic Injustice, edited by Ian James Kidd, José Medina, and Gaile Pohlhaus Jr., New York: Routledge, Taylor \& Francis Group, 2017, pp.324-355.

Lipman, Matthew. Thinking in Education 2nd ed. New York: Cambridge University Press, 2003.

Lipman, Matthew. "Philosophy for Children: Some Assumptions and Implications," in Ethics in Progress, Vol. 2, No. 1, 2011.

Lone, Jana Mohr. "Philosophical Thinking in Childhood," in The Routledge Handbook of the Philosophy of Childhood and Children, edited by Anca Gheaus, Gideon Calder and Jurgen de Wispelaere, New York: Routledge, 2019. 
mapping identity prejudice: locations of epistemic injustice in philosophy for/with children

Madrid, María Elena. "Multiculturalism, Extreme Poverty, and Teaching P4c in Juchitán: A Short Report on Research," in Childhood E Philosophy Vol. 4, No. 8, 2008, pp.125-135.

Medina, Jose. "Epistemic Injustice and Epistemologies of Ignorance," in The Routledge Companion to the Philosophy of Race, edited by Paul C. Taylor, Linda Martin Alcoff, and Luvell Anderson, New York/London: Taylor and Francis, 2017, pp.247-260.

Murris, Karin. "The Epistemic Challenge of Hearing Child's Voice," in Studies in Philosophy and Education, 2013, pp.245-259.

Rainville, Hell. "Philosophy for Children in Native America. A Post-Colonial Critique," in Analytic Teaching and Philosophical Praxis, vol. 21, no. 1, 2001, pp.65-77.

Reed-Sandoval, Amy and Alain Sykes, A. "Who talks? Who listens? Taking 'positionality' seriously in philosophy for children," in The Routledge International Handbook of Philosophy for Children, edited by Maughn Rollins Gregory, Joanna Haynes and Karin Murris, 2017, pp.219-226.

Santoro, Daniele \& Manohar Kumar, "Being Bound to Fail: How Epistemic Injustice fails Educational Opportunities," a paper presented to the IMERA Resident Seminar (2014), the II Philosophy of Education Conference, Bangalor (2014), retrieved April 20, 2018, from: https://imera.univ-amu.fr/sites/imera.univamu.fr/files/being_bound_to_fail.how_epistemic_injustice_fails_educational_opport unities_draft_0.pdf.

Schües, Christina. "Epistemic Injustice and Children's Well-being," in Justice, Education and the Politics of Childhood: Challenges and Perspectives, edited by Johannes Drerup, Gunter Graf, Christoph Schickhardt, Gottfried Schweiger, Switzerland: Springer, 2016, pp.155-170.

Sharp, Ann Margaret. "The Other Dimension of Caring Thinking (with a new commentary by Philip Cam)," in Journal of Philosophy in Schools 1 (1), 2014.

Sherman, Benjamin R. \& Stacey Goguen. "Introduction" in Overcoming Epistemic Injustice: Social and Psychological Perspectives, edited by Benjamin R. Serman \& Stacey Goguen London/New York: Rowman \& Littlefield International, Ltd., 2019, pp.1-14.

Steele, Claude. "A Threat in the Air: How Stereotypes Shape Intellectual Identity and Performance," in American Psychologist by the American Psychological Association, Inc. Vol. 52, No. 6, 1997, pp.613-629.

received in: 22.01.2020

approved in: 05.03.2020 